\title{
主観的評価に基づくオープンプランオフィスにおける 執務作業時のサウンドマスキングの適用に関する検討 APPLICATION OF SOUND MASKING SYSTEM AT DESK WORKING
IN OPEN PLAN OFFICES BASED ON SUBJECTIVE EVALUATIONS
}

\author{
橋本 修*, 茨木大輔** \\ Osamu HASHIMOTO and Daisuke IBARAKI
}

\begin{abstract}
The purpose of this study was to examine masking systems between desks in open plan offices installed with an appropriate sound masking system. Word intelligibility tests for unwanted speech interference from nearby workstations, and subjective judgements on the degree of discomfort of masking sound were conducted in a simulated office workplace. The results were as follows: (1) The level of masker sound could be decreased to 5-10 dB when focused on desk work relative to the masking level in non-desk work; (2) We showed that the optimum masking level in a desk work environment is a target/masker ratio of $-2 \mathrm{~dB}$.
\end{abstract}

Keywords : Sound Masking, Open Plan Office, Speech Privacy,Word Intelligibility, Task Disturbance, Office Work サウンドマスキング，オープンプランオフィス，スピーチプライバシー，了解度，作業への妨害感，執務作業

1. はじめに

近年、執務空間におけるデスクレイアウトの柔軟性や執務者間の コミュニケーションの活性化を望む立場から、壁や間仕切りを用い ないオープンプランオフィスが普及し始めている。このようなオフ ィス内では、PC 作業など個人で事務作業を行う者と複数人で会話 を行う者らが近接する位置関係となりやすい。よって建築的に開放 的な空間が実現される半面、音響面では会話音声の漏洩によって個 人の執務作業が妨害される問題や話者のプライバシー性が失われる 場面が発生することが懸念される。これらの問題の対策法の一つと してサウンドマスキングシステムが利用されている。

サウンドマスキングシステムは、欧米においては、金融や保健、 医療関係などプライバシー性が重要視されるオフィス空間のみなら ず、一般のオフィス空間にも積極的に導入されている 1)。しかし、 建築空間の用途や、その場で情報を共有寸る人の立場によって、求 められる秘話性の程度や要求性能が変わるため、それぞれの環境に 適したマスキング条件を検討寸る必要があるものと考えられる。

わが国では、これまで薬局や診察室を対象としたスピーチプライ バシーについての研究や 2)344)、オフィス内の間仕切り壁で隔てられ
た会議室における会話音声の漏洩を扱った研究例が多くあるが 5)6)、 これらは比較的静肃な空間で秘話性が要求される環境での検討例で あり、評価者の聴取態度は漏洩してくる音声に意識集中した環境を 想定した状況で検討が行われている。

一方、オープンプランオフィスでは、空間内の音声の伝送経路に 物理的な遮蔽環境を整えにくいことから、秘話性の高い音響空間を 実現しにくい場合が多く、他の執務者が発する会話音によって自ら の執務環境が侵害される状況が問題となる場合が考えられる。また、 一般に執務者はある程度作業に集中している状況での聴取態度であ ることが特徴的である。欧米では、このような他人の会話による妨 害感の影響を考慮して執務時の音環境評価を行っており、漏洩して くる会話音の明瞭性に対する目標值が音場の評価方法や測定法にお いても用いられ 7)8)、さらに、オフィスにおけるノイズマスカーの適 正レベルについての検討も行われている 9)。

しかし、現在、日本においては、このような執務時における妨害 感の評価法や測定法は確立されていない。そこで、執務作業時にお けるサウンドマスキングの有効性や適用範囲を示す上で、主観的評 価による実験的検討結果を用いて検討していくことが重要と考えた。

\footnotetext{
$*$ 日本大学理工学部建築学科 准教授 $\cdot$ 工博 Assoc. Prof., Dept. of Architecture, College of Science and Technology, Nihon Univ.,

** 東日本旅客鉄道 工修 Dr. Eng. East Japan Railway Company, M. Eng.
} 
国内おける執務時を想定したマスキング下での主観的評価に関寸 る既往研究では、清水ら 10)、渡曾ら 11) が漏洩音となる会話音の明 瞭性とマスカーによる喧騒感が執務者の妨害感評価に影響を及ぼす ことや、さらに執務者の作業集中の程度などによってマスキング効 果が变わる可能性を実験結果から示しているが、評価者の執務態度 の違いよる影響を考慮したマスキングレベル等については、さらな る検討が必要であると考えられる。

そこで本研究では、執務時の作業態度による影響について着目し、 漏洩会話音の明瞭性の低減とマスカー音の喧騒感による妨害度の低 減の双方の立場から作業への妨害感を最小限に抑えられるマスキン グ条件を考察し、オフィスでの執務作業時におけるサウンドマスキ ングの適用条件に関する知見を得ることを目的とした。

まず、上述の二つの評価の側面のうち、会話のプライバシー性保 護の面から漏洩音の了解性についての主観評価実験を行い、マスカ 一音の再生方向やマスカー音の種類を変えた実験結果から、必要之 されるマスキングレベルを考察した。次に、作業への妨害感につい ての評価を考慮したマスキングレベルの検討を行い、上記の会話の プライバシー性保護の面から必要とされるマスキングレベルの結果 と合わせて総合的な評価を行った。さらに、マスカー音の周波数特 性を考慮することで妨害感の低減が図れるかについても検討した。

なお、本研究ではマスカーの再生条件と執務者態度に主眼をおい た検討としたため、室内の音の伝搬経路にパーティションなどの遮 蔽物は設置せず、室内の内装は一定の条件で実験を行った。

\section{2. 漏洩音の聴き取り印象評価によるマスキングレベルの検討}

個人の執務空間と共用空間が近接する場合や、他者の会話音声が 個人で執務作業をするエリアに漏洩するオフィスレイアウトの状況 を想定した（図 1)。これを模擬した実験環境を、教室空間内（約 $500 \mathrm{~m}^{3}$ 、室内平均吸音率約 0.2 ) の中央部に再現し（図 2)、執務者 （被験者）に対して隣接空間から漏洩音（音源：音声スピーカ）が 聞こえてくる状況を設定した。再生スピーカには KEF(BBC LS3/5a class2 monitor）を用いた。

オフィスにおけるマスキング音の再生方式は、欧米などで一般的 に用いられている天井面から部屋全体にマスカー音を再生する方式 の他、スピーカの配置によってマスカー音に指向性を持たせて再生 寸る方式の主に 2 つ方式が考えられる。マスカー音の再生方法に ついては、上野ら 12)、Bradley ら 13)、清水ら 14)、藤原 ${ }^{15}$ )の検討結 果や、別報 16)での基礎実験の検討結果から、ターゲットとなる漏洩 音の到来方向と同方向からマスカーを再生する方が、非同方向から 再生する場合よりもマスキング効果が高いことが示されている。

そこで本検討では、これら 2 つマスキング音の再生条件を用い ることとし、図 2 に示したように、被験者に対して水平 4 方向のス ピーカからマスカー音を再生する条件 (以降、非方向性マスキング と示寸）と、ターゲットとなる漏洩音の到来方向と同一方向からマ スカーを再生する条件（以降、方向性マスキング（同方向）と示寸) の 2 つの実験パターンについて比較検討を行った。マスキング用の スピーカは漏洩音の再生に用いたスピーカと同一の機器で、4 方向 のスピーカにディレイと位相のフィルター処理を施し被験者位置で 無相関な再生音となるようにした。なお、本検討での実験環境では 後述するように既設のシーリングスピーカを背景騒音の再生のため
に利用したため、被験者に対して水平 4 方向のスピーカからマスカ 一音を再生することによって非方向性マスキングの再生条件を設定 した。また、漏洩音を再生する音声スピーカと被験者位置との距離 $(4 \mathrm{~m})$ は、スピーカの指向性からほぼ臨界距離となる位置を目安に、 実験環境で実際にスピーカから再生した音声を聞きながら直接音が 自然な侵入音として認識できる距離を調整して決定した。

実験に用いたマスカー音源と作業条件の内容を表 1 に、被験者位 置で測定したマスカー音源の周波数特性を図 3 に示す。漏洩音には

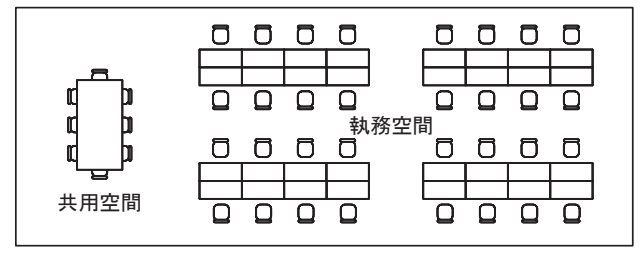

図 1 オープンプランオフィスレイアウト例

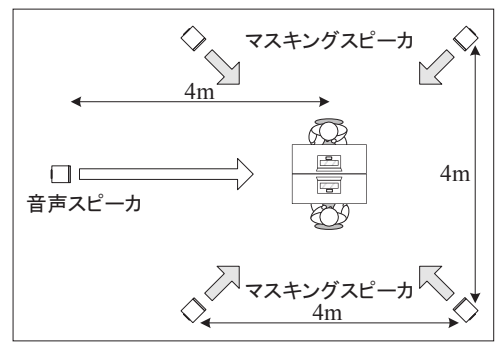

非方向性マスキング

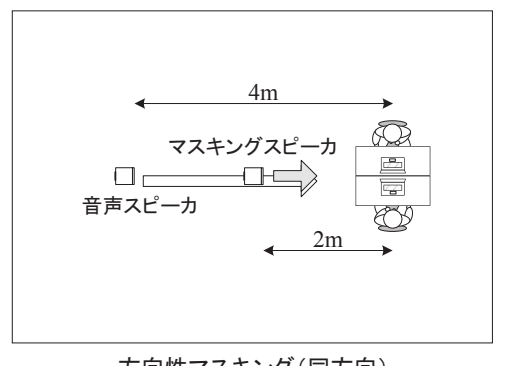

方向性マスキング(同方向)

図 2 実験条件（漏洩音の聴き取り）

表 1 マスカー音源と作業条件

\begin{tabular}{|c|c|c|}
\hline \multicolumn{2}{|c|}{ マスカー音源 } & 内容 \\
\hline \multicolumn{2}{|c|}{ ピンクノイズ } & 125Hz 8000Hzに帯域を制限したもの \\
\hline \multicolumn{2}{|c|}{ 空調音 } & 教室の空調音を録音したもの (-5dB/oct) \\
\hline \multicolumn{2}{|c|}{ 音楽 } & モーツアルト クラリネット協奏曲イ長調K. 622 第2楽章 アダージョ \\
\hline \multicolumn{2}{|c|}{ 環境音 } & 水流音 \\
\hline \multicolumn{2}{|c|}{ 作業条件 } & 内容 \\
\hline 非作業時 & 作業なし & 音声を聴取する。 \\
\hline \multirow{2}{*}{ 作業時 } & PC作業 & 用意された新聞記事のタイピングを行う。 \\
\hline & 対面会話 & 対面者と会話を行う。 \\
\hline
\end{tabular}

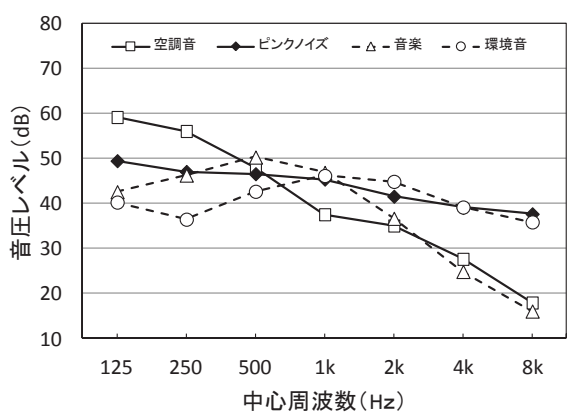

図 3 マスカー音の周波数特性 
男性による小説の朗読音声を用い、再生レベル（LAeq）は音声スピ 一カ正面から $1 \mathrm{~m}$ 点で $55 \mathrm{~dB}$ (聴取位置で $48 \mathrm{~dB}$ ) になるように設定 した。マスカーにはピンクノイズ、空調音、音楽、環境音の 4 種を 用い、マスキングレベルは被験者位置でのターゲット音（漏洩音） とマスカー音のレベル差（T/M 比）が+8dB、 $+3 \mathrm{~dB} 、-2 \mathrm{~dB}$ (マスカ ーレベルが聴取位置で $50 \mathrm{~dB}) 、-7 \mathrm{~dB} 、-12 \mathrm{~dB}$ となる 5 条件とした。 また、実験はマスカーを再生しない条件（マスカーなし）も加えて 行った。なお、すべてのパターンにおいて天井のシーリングスピー カから空調音を再生し（被験者位置で $40 \mathrm{~dB}$ ( LAeq)) 常に背景騒 音がある条件で実験を行った。また、上記の漏洩音およびマスカー 音の再生レベルの設定は、背景騷音となる空調音を停止した状態で 行った。

実験で被験者に与えた作業条件は、表 1 に示した非作業時の「作 業なし」と作業時の「PC 作業」「対面会話」の 3 パターンとした。 「作業なし」は、何もせずに椅子に座っている状態で、「PC 作業」 は、初見の新聞記事を机上のノート PC の画面横に提示し、被験者 にこれを見ながら連続作業として記事の文章をそのままタイプ打ち (MS-Word アプリを使用) させた。また「対面会話」では、椅子 に座って対面する相手と 2 名 1 組で、被験者に選んでもらったある テーマについて自由会話をしてもらった。ここでは、日常行ってい るような態度で対話し、またできるだけ話の間が途切れてしまわな いよう連続した会話を行ってもらうように教示を行った。

被験者に作業条件を 90 秒間集中して体験してもらった後に、表 2 に示す「漏洩音の聴き取り（不明瞭さ）」について 5 段階のカテゴ リー評価を行った。なお回答中はマスカー音の再生を停止し、背景 騒音 (空調音) のみが再生する状況とした。評価実験は、マスカー 種ごとに T/M 比の条件をランダムに提示して行うことを 1 シリーズ とし、これを作業条件ごとに時間をあけて実験を行い、さらにここ までの実験の流れでマスカーの再生方向の条件を変えて実験を行っ た。被験者は「作業なし」と「PC 作業」の条件では 11 名、「対面 会話」の条件では 10 名で、いずれも 20 代学生である。

マスカー音の再生方向の違いによる影響について、マスカー種別、 $\mathrm{T} / \mathrm{M}$ 比ごとの「漏洩音の聴き取り (不明瞭さ)」の印象評価の試験 結果を比較したところ、今回検討を行ったほとんど全ての実験条件 において有意な差がみられなかった（有意水準 $>10 \%$ ）ので、ここ では非方向性マスキングの条件についての結果をもとに考察を示寸。 マスカーなしの条件を含む 6 つのマスキングレベル条件における 「漏洩音の聴き取り(不明瞭さ)」の印象評価の結果を図 4 に示す。 ここで評価值が 3 以上（話中の単語が聴き取れる場合があるが、内 容は理解できない）をオフィスで必要なマスキング性能と判断する と、それを満たす T/M 比は、「作業なし」では- $12 \mathrm{~dB}$ 以下、「PC 作 業」では-7dB、「対面会話」では- $2 \mathrm{~dB}$ となり、作業条件によって差 異が生じている。また、作業時には作業に意識が向くことで、マス カーレベルを非作業時よりも「PC 作業」では約 $5 \mathrm{~dB}$ 以上、「対面 会話」では約 $10 \mathrm{~dB}$ 以上軽減できる可能性が示された。「対面会話」 でよりマスカー音の再生レベルを低減できる可能性となったのは、 会話に意識が向いたことに加えて、会話時の会話音声が漏洩音を不 明瞭にするためのマスカーとして寄与した可能性が推測される。

これらの結果から「漏洩音の聴き取り (不明瞭さ)」の印象評価結 果より、会話のプライバシー性の面から必要とされるマスキングレ
ベルは、T/M 比が-7dB〜-2dB 以下の条件となった。

\section{3. 単語了解度によるマスカー音の再生方向の検討}

2 章での実験結果から、今回の実験条件では、マスカー音の再生 方向の違いによる「漏洩音の聴き取り（不明瞭さ）」印象への影響は 顕著にみられなかった。しかし、被験者からの報告で音声の語音の 明瞭性については聴き取り感に違いがあるとの意見があり、また、 実験条件での主観評価印象をより定量的な試験結果で評価する方法 として、同じ再生条件で単語了解度試験による検討を行った。 単語了解度試験の実験環境を図 5 に示す。漏洩音を想定した音声

\section{表 2 漏洩音の聴き取り印象評価（不明瞭さ）}

\begin{tabular}{|l|l|}
\hline 1 & 完全に話が聴き取れ、理解できる \\
\hline 2 & ほとんどの話が聴き取れ、理解できる \\
\hline 3 & 話中の単語が聴き取れる場合があるが、内容は理解できない \\
\hline 4 & 話をしているのはわかるが、単語が聴き取れない \\
\hline 5 & 話をしていること自体気がつかない \\
\hline
\end{tabular}
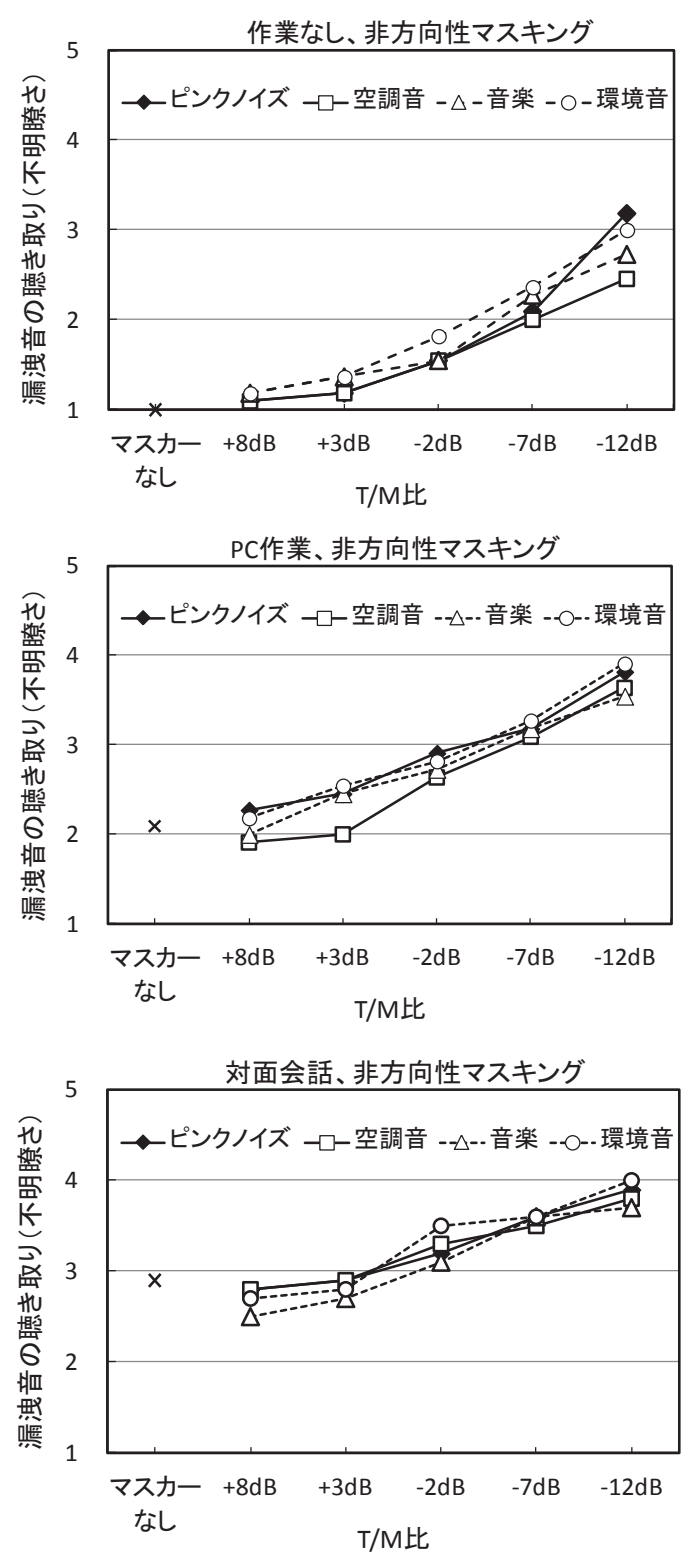

図 4 漏洩音の聴き取り印象評価（不明瞭さ） 
スピーカを被験者横に、対面者の声を想定した音声スピーカを被験 者正面に設置した。「作業なし」と「PC 作業」の条件では横のスピ 一カから単語了解度の音声を再生し、「対面会話」の条件では正面と 横のスピーカからそれぞれ別の単語了解度の音声を同時に再生した。 単語了解度の音声は親密度 5.5 7.0のもの（男声）17)を使用し、再 生レベル（LAeq） はスピーカ正面から $1 \mathrm{~m}$ 点で $55 \mathrm{~dB}$ になるように 設定した。

「作業なし」と「PC 作業」の条件では、椅子に静坐している状態 で横から聞こえてくる単語了解度の音声について、聴き取った単語 を書き取ってもらった結果をもとに、正答率で評価した。「対面会話」 の条件では、対面会話時に相手の言葉に意識を集中している状沉を 考慮し、被験者に正面から再生される音声に集中寸るよう教示を行 い、正面からの音声の他に横からの漏洩音の音声も含めて聞こえた 全ての音声について聴き取った単語を全て書き取ってもらった。た だし試験結果としては、正面と横の音声別に正答率は分けて評価し、 それぞれ「対面会話」の正面および横の了解度とした。

なお、「PC 作業」のように作業内容によっては、被験者が作業に 集中しながら同時に音声に意識を向けて単語了解度の回答をするこ とには無理があったので、ここでは作業を行わない環境における聴 感試験の結果を用いて考察した。よって実際の作業時においては、 ここで得られた結果以上のマスキング効果が得られるものと予想さ れる。

単語了解度試験の実験条件を表 3 に示す。実験は 2 章で行った実 験と同じく、4 種のマスカーと 3 つの作業条件、さらにマスカーの 再生方向が異なる 2 条件で実験を行ったが、マスカー音の再生条件 については、前章の実験で「漏洩音の聴き取り（不明瞭さ）」が 3 （話中の単語が聴き取れる場合があるが、内容は理解できない）と評 価された条件に限定した。なお、方向性マスキング（同方向）時の マスカーに音楽を用いた条件は、評価が 3 に該当する条件がなかっ たので実験パターンに入っていない。了解度試験の手順は、作業条 件ごとにマスカー種をランダムに提示し、次にマスカーの再生方向 を変えて実験を行った。被験者は 20 代学生 9 名である。

単語了解度試験の結果を表 4 亿示寸。「作業なし」と「PC 作業」 の条件で結果を比較すると、平均で約 $20 \%$ の了解度正答率の差が生 じており、「漏洩音の聴き取り（不明瞭さ）」が同程度に評価されて いる音響条件であっても、単語了解度の正答率では約 $20 \%$ 差があ る状況となっていることが示された。なお、「対面会話」の条件では、 正面の音声の了解度は高い水準（90\%以上）が保たれており、漏洩 音の内容が理解できない程度のマスキング条件においても相手の声 は十分聴き取れる状況にあることが確認できる。また、マスカー音 の種類を比較すると、環境音（水流音）の条件が最も了解度が低い 傾向となった。

サウンドマスキングにおけるマスカー音の再生方向の影響につい ては、既往の研究報告 12)13141415)から、ターゲット音に対してマスカ 一音を同方向から再生する方が、高いマスキング効果が得られるこ とが報告されている。本検討での実験結果から、マスカー音の再生 方向の違いについて考察すると、2 章での検討における漏洩音の聞 き取り(不明瞭さ)」印象評価においては有意な差が見られなかった が、漏洩音の語音明瞭性の評価である単語了解度の正答率で約 $20 \%$ 低い結果が得られ、上記の既報の結果と同様に、ターゲット音とな

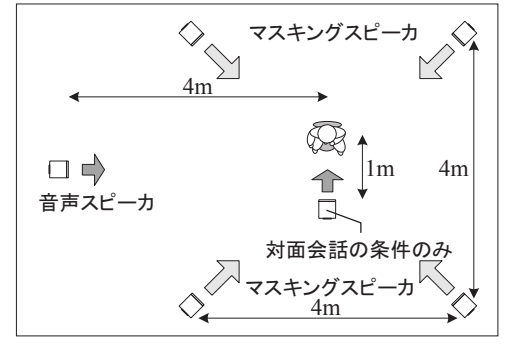

非方向性マスキング

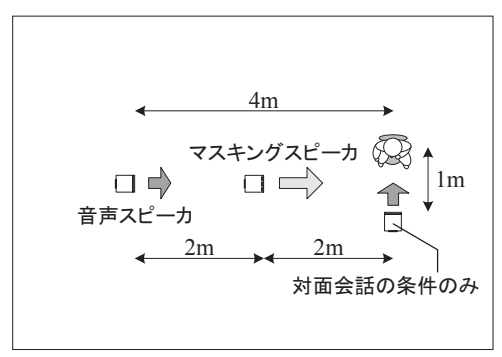

方向性マスキング(同方向)

図 5 実験条件（単語了解度試験）

\section{表 3 単語了解度試験の実験条件}

\begin{tabular}{|c|c|c|c|c|c|}
\hline \multirow{2}{*}{ 背景騒音 } & \multirow{2}{*}{ 再生方向 } & \multirow{2}{*}{ マスカー } & \multicolumn{3}{|c|}{$\mathrm{T} / \mathrm{M}$ 比 (dB) } \\
\hline & & & 作業なし & PC作業 & 対面会話 \\
\hline \multirow{8}{*}{$40 \mathrm{dBA}$} & \multirow{4}{*}{$\begin{array}{l}\text { 非方向性 } \\
\text { マスキング }\end{array}$} & ピンクノイズ & -12 & -7 & -2 \\
\hline & & 空調音 & -12 & -7 & -2 \\
\hline & & 音楽 & -12 & -7 & -2 \\
\hline & & $\begin{array}{l}\text { 環境音 } \\
\end{array}$ & -12 & -7 & -2 \\
\hline & \multirow{4}{*}{$\begin{array}{c}\text { 方向性 } \\
\text { マスキング }\end{array}$} & ピンクノイズ & -12 & -7 & +3 \\
\hline & & 空調音 & -12 & -7 & +3 \\
\hline & & 音楽 & - & - & +3 \\
\hline & & 環境音 & -12 & -7 & +8 \\
\hline
\end{tabular}

表 4 単語了解度試験結果

\begin{tabular}{|c|c|c|c|c|c|}
\hline \multirow[b]{2}{*}{ 背景騷音 } & \multirow[b]{2}{*}{ 再生方向 } & \multirow[b]{2}{*}{ マスカー } & \multicolumn{3}{|c|}{ 正答率 (\%) } \\
\hline & & & 作業なし & PC作業 & $\begin{array}{l}\text { 対面会話 } \\
\text { (正面) } / \text { (横) }\end{array}$ \\
\hline \multirow{8}{*}{$40 \mathrm{dBA}$} & \multirow{4}{*}{$\begin{array}{c}\text { 非方向性 } \\
\text { マスキング }\end{array}$} & ピンクノイズ & 20 & 49 & $90 / 18$ \\
\hline & & 空調音 & 51 & 81 & $94 / 39$ \\
\hline & & 音楽 & 88 & 93 & $99 / 33$ \\
\hline & & 環境音 & 6 & 28 & $95 / 12$ \\
\hline & \multirow{4}{*}{$\begin{array}{c}\text { 方向性 } \\
\text { マスキング }\end{array}$} & ピンクノイズ & 3 & 18 & $97 / 20$ \\
\hline & & 空調音 & 25 & 56 & $97 / 31$ \\
\hline & & 音楽 & - & - & $97 / 37$ \\
\hline & & 環境音 & 4 & 14 & $96 / 21$ \\
\hline
\end{tabular}

る漏洩音と同方向からマスカーを再生する方が高いマスキング効果 を得られる傾向が示された。

よって、執務者が作業集中時および作業を休んでいる場合での漏 洩してくる会話音の明瞭性による妨害感をより軽減する立場を考え ると、ターゲット音となる漏洩音と同方向から再生する方向性マス キング（同方向）を行うことが望ましいことが示唆された。

しかし、今回の実験結果は侵入してくる漏洩音に対して方向感が ある条件で行った検討であり、漏洩音を再生する音声スピーカと被 験者間との距離の違いによって漏洩音に対しての方向感が異なるこ とやマスキング用のスピーカの設置条件等の違いが主観評価の結果 に与える影響については、さらに検討を行う必要があると考える。

\section{4. 執務作業時の妨害感評価によるマスキングレベルの検討}

2 章、3 章では、会話のプライバシー性保護の面からオープンプ ランオフィスで必要とされるマスキングレベルについて検討した。 
次にマスカー音の再生が執務作業時の妨害感に与える影響ついて考 察し、これらの結果から執務作業への妨害感を最小限に抑えられる 必要マスキングレベルについて総合評価を行った。

これまで生産性と関連した執務（文章作成、計算、記憶など）に おいて、騒音の他に会話音声が執務の妨害感に影響を与えているこ とが示されている 18199)。さらに清水ら 10)は、オフィスにおけるサ ウンドマスキング音の評価についての検討で、執務者が受ける音環 境の妨害要因には、他の会話音の了解性とマスカー音の喧騒感が関 係することを示している。

そこで、本検討ではこの点を参考にして、2 章で述べた漏洩音の 聞き取り印象におけるカテゴリー評価に加えて、マスキング環境に おける執務作業時の妨害要因の検討として、「マスカー音の不快感」、 「作業への妨害感」についてのカテゴリー評価を行った。これに、対 面会話時の評価として「対面者の声の聴き取りにくさ」の項目を加 え、さらに全体印象評価として「執務空間としての好ましさ」の項 目を加えて検討を行った。 5 段階のカテゴリー評価の内容を表 5 に 示す。なお、作業への影響を判断する項目として「作業への妨害感」 の評価には、漏洩音とマスカー音の双方の影響が関係すると予想さ れた。そこで、マスカー音の聞こえによる妨害感への影響の程度を 把握するために、被験者にマスカー音のみを対象とした不快感（マ スカー音の聞こえはじめから不快まで）を回答するように教示を与 えて「マスカー音の不快感」の評価を行った。なお全ての実験条件 において漏洩音の再生レベルは一定なので、漏洩音は「作業への妨 害感」に一定の負荷を与えていると考えられるが、漏洩音が不快と 感じる再生レベルの条件とはなっていない。

また、「作業への妨害感」については、評価値が 4 （作業にやや支 障が出る) 以上を作業への妨害を感じている状況と判断し、別途、「妨 害を感じた人の割合」を算出した。被験者は「作業なし」と「PC 作 業」の条件では 11 名、「対面会話」の条件では 10 名で、いずれも 20 代学生である。

実験を行った環境は 2 章の実験条件と同様で、実験パターンは 4 種のマスカーと 3 つの作業条件、さらにマスカーの再生方向が異な る 2 条件の組み合わせで実験を行い、マスカー種ごとに T/M 比の条 件をランダムに提示して行うことを 1 シリーズとし、これを作業条 件ごとに時間をあけて実験を行い、さらにマスカーの再生方向の条 件を変えて実験を行った。

なお、マスカーの再生方向の違いによる影響について、マスカー 種別、T/M 比ごとの「作業への妨害感」の印象評価の試験結果を比 較したところ、今回検討を行ったほとんどの全ての実験条件におい て有意な差がみられなかった（有意水準＞10\%）ので、ここでは非

表 5 カテゴリー評価（妨害感評価）

「マスカ一音の不快感」
\begin{tabular}{|l|l|}
\hline 1 & 全〈気にならない \\
\hline 2 & やや気になる \\
\hline 3 & 気になる \\
\hline 4 & 不快 \\
\hline 5 & 非常に不快 \\
\hline
\end{tabular}
\begin{tabular}{|l|l|}
\hline 1 & 作業への妨害感」 \\
\hline 2 & 作業にはは影響しないはとんど響しない \\
\hline 3 & どちらともいえない \\
\hline 4 & 作業にやや支障が出る \\
\hline 5 & 作業に大きな支障が出る \\
\hline
\end{tabular}
「対面者の声の聴き取りにくさ」 1 聴き取りにくくない 2 やや聴き取りにくい 3 聴き取りにくい 4 かなり聴き取りにくい 5 非常に聴き取りにくい 「執務空間としての好ましさ 1 全く好ましくない 2 やや好ましくない 3 どちらともいえない 4 やや好ましい \begin{tabular}{lll}
4 & やや好ましい \\
\hline 5 & 非常に好ましい
\end{tabular}
方向性マスキングの条件についての結果をもとに考察を示す。

「マスカー音の不快感」の結果を図 6 に示す。

これをみると、マスキングレベルが上昇するに伴い不快感が増し
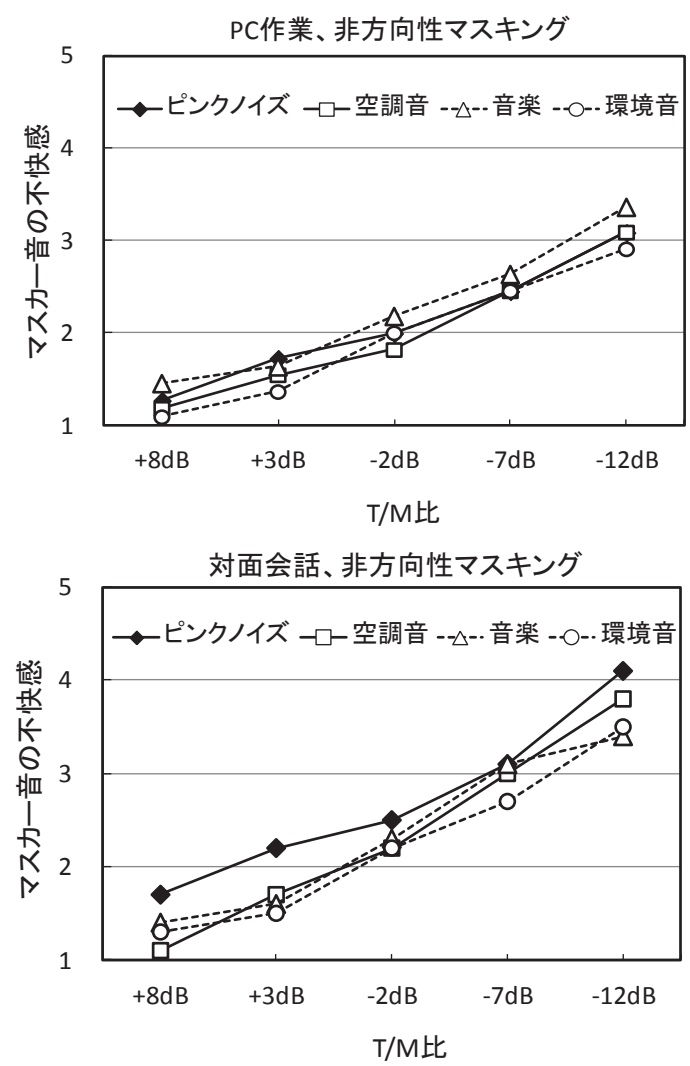

図 6 マスカー音の不快感

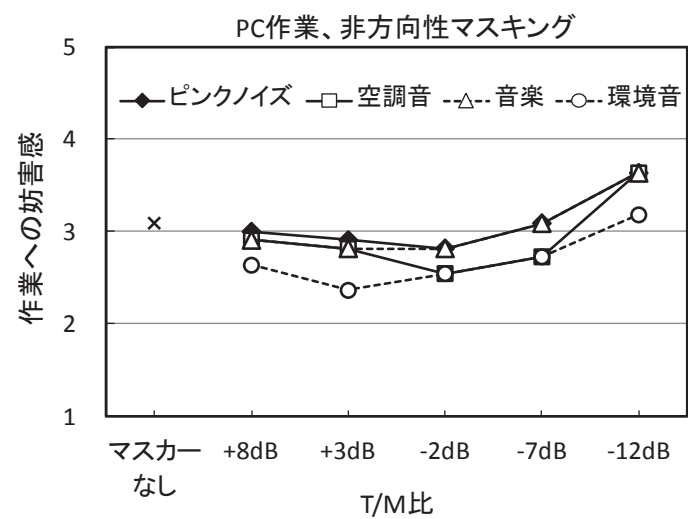

対面会話、非方向性マスキング

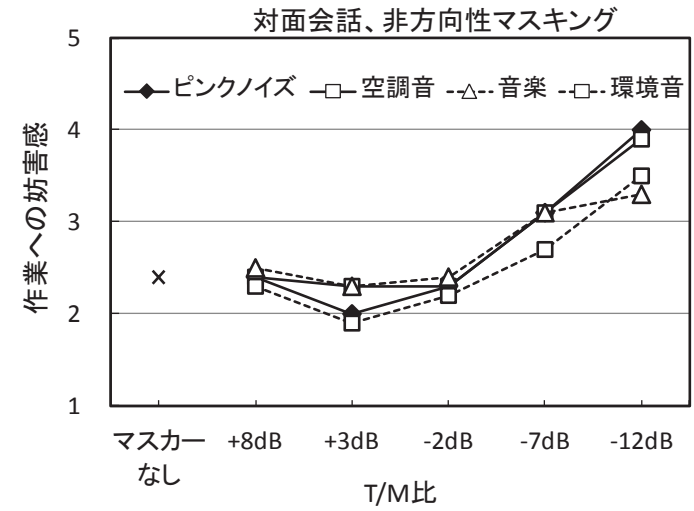

図 7 作業への妨害感 

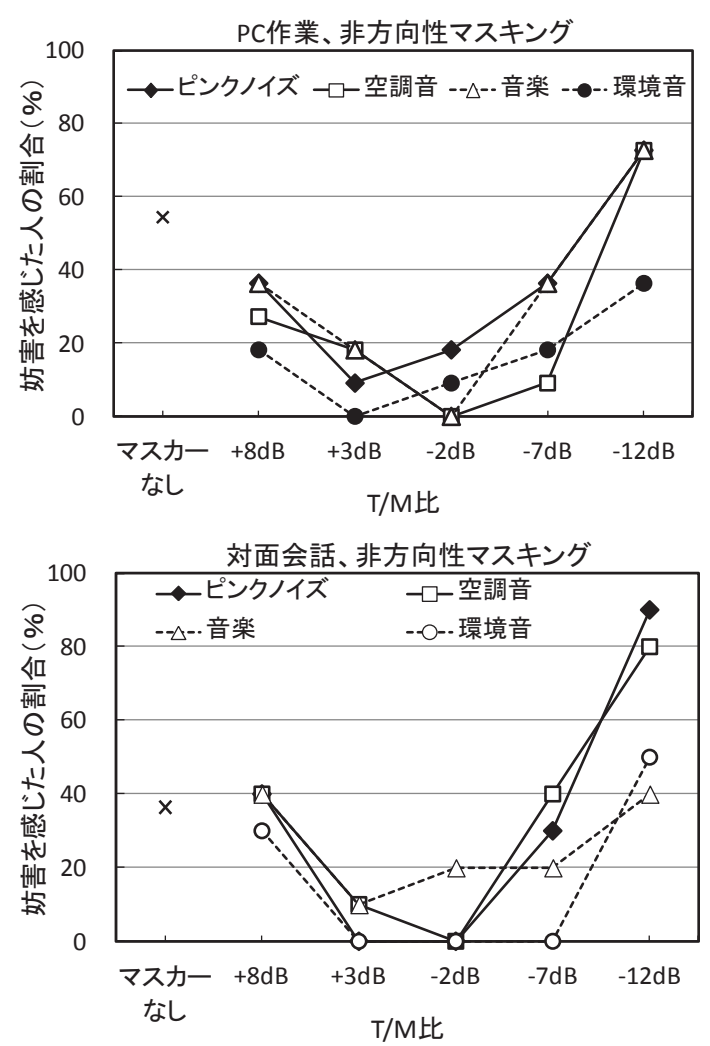

図 8 妨害を感じた人の割合

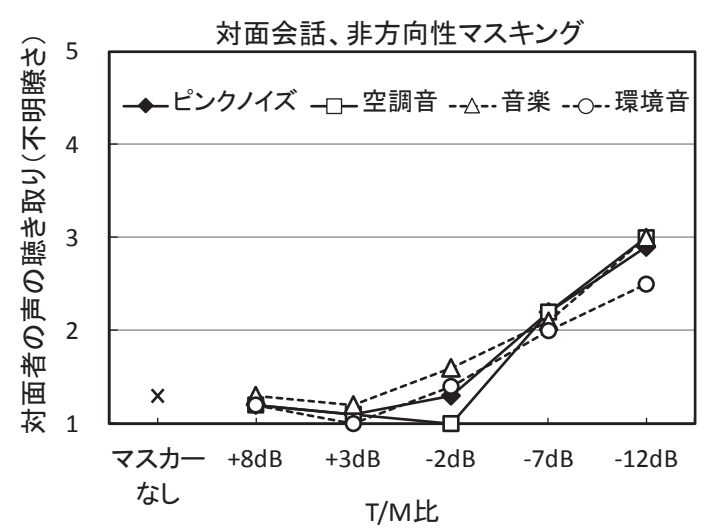

図 9 対面者の声の聴き取りにくさ

ている。また、マスキング音の種類で比較すると、「対面会話」での 条件で不快感がピンクノイズの条件 (T/M 比+3～+8) で大きくなる 傾向があるが、「PC 作業」の条件では全条件で有意な差は見られな かった。

図 7 の「作業への妨害感」の結果において、評価值の 3（どちら ともいえない）以下を作業への妨害を感じないと判断すると、それ を満たす $\mathrm{T} / \mathrm{M}$ 比は- $2 \mathrm{~dB}$ 以上の条件となる。

$「 \mathrm{PC}$ 作業」の条件について考察すると、図 6 からマスカー音の再 生レベルが小さいほど（T/M 比が大きいほど）、「マスカーの不快感」 は軽減される傾向となり、マスカーの影響度が小さくなっているこ とが分かる。一方、図 7 の「作業への妨害感」の結果を見ると、マ スカーなしの条件および $\mathrm{T} / \mathrm{M}$ 比- $2 \mathrm{~dB}$ 以上の範囲で一定の妨害感が あることが示されている。この結果を 2 章での漏洩音の聞き取り印 象の結果（図 4）と併せて考えると、マスカー音のレベルが小さい
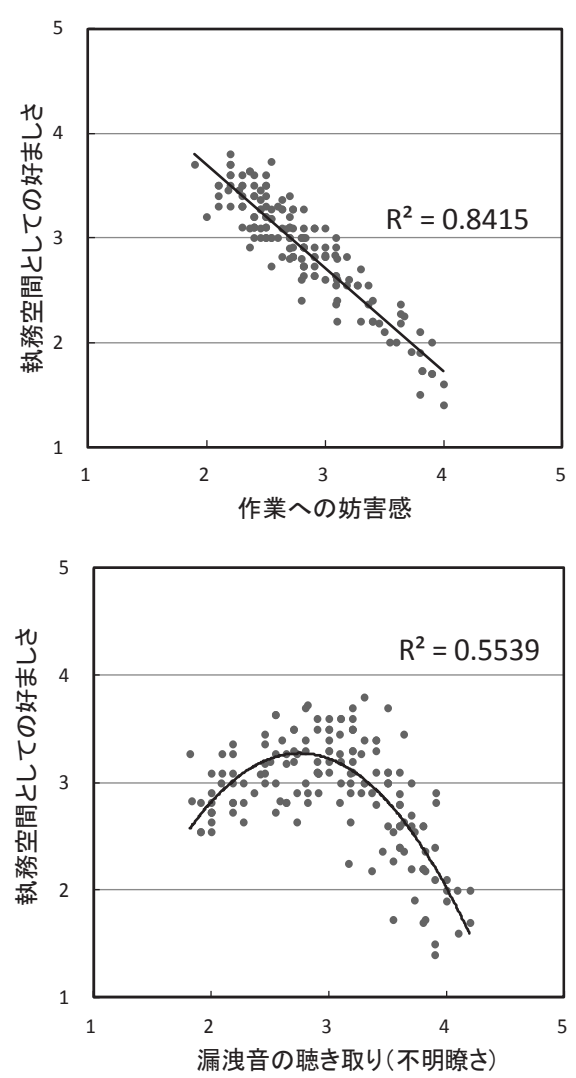

図 10 執務空間としての好ましさと作業への妨害感 及び漏洩音の聴き取り (不明瞭さ) との関係

ほど音声が理解できる状況となり、漏洩音の明瞭性が「作業へ妨害 感」に与える影響度が大きくなることが推察される。一方、マスカ 一音の再生レベルが大きいほど（T/M 比が小さいほど）、図 4 の結 果からマスカーによるマスキング効果によって漏洩音の明瞭性は低 下寸るが、「マスカー音の不快感」は増加して「作業への妨害感」が 増す傾向が示されている。 $\mathrm{T} / \mathrm{M}$ 比が- $7 \mathrm{~dB}$ 以下では、「マスカー音の 不快感」は評価 3 の（気になる）から評価 4 の（不快）の評価とな り、「作業への妨害感」は評価 3 の（どちらともいえない）から作 業に支障が出る傾向にある。よって、このように $\mathrm{T} / \mathrm{M}$ 比が小さい条 件下では、マスカー音の再生レベルが「作業へ妨害感」に与える影 響度が大きくなることが推察される。また図 8 に示す「妨害を感じ た人の割合」では、 $\mathrm{T} / \mathrm{M}$ 比が- $2 \mathrm{~dB} \sim+3 \mathrm{~dB}$ の範囲で最も低い結果と なっており、これと比較して今回の条件での $\mathrm{T} / \mathrm{M}$ 比の上限と下限に 近い範囲では妨害感の影響がより強い傾向となっている。

次に、図 7 の「対面会話」の条件についてみると、「PC 作業」の 条件と同様な傾向が得られているが、T/M 比が- $2 \mathrm{~dB}$ を下回ると妨 害感がより顕著に増加している。「対面者の声の聴き取りにくさ」(図 9) においても $\mathrm{T} / \mathrm{M}$ 比が-2 $\mathrm{dB}$ を下回ると聴き取りにくくなっている ことから、対面会話時においては、対面者の声の聴き取りにくさも 妨害感の要因になっていると考えられる。

以上の結果から、今回のマスキング条件における $\mathrm{T} / \mathrm{M}$ 比の上限と 下限それぞれの状況においては、作業への妨害感の要因が異なるこ とが示唆された。また、これらの実験結果から、執務作業時の妨害 感の評価から許容できると判断されるマスキングレベルの目安とし 
て、T/M 比が- $2 \mathrm{~dB} \sim+3 \mathrm{~dB}$ の条件が得られた。

さらに、全ての実験条件について、被験者に全体印象としての「執 務空間としての好ましさ」を評価してもらった結果と、「作業への妨 害感」及び「漏洩音の聴き取り(不明瞭さ)」の関係を図 10 に示す。 これをみると、「執務空間としての好ましさ」は、「作業への妨害感」 と直線相関（ $\mathrm{R}^{2}=0.8415 ）$ の関係性が示され、作業への妨害を感じ ないことが執務者にとって好ましい環境であることが確認できる。 一方、「執務空間としての好ましさ」と「漏洩音の聴き取り (不明瞭 さ)」との間には 2 次の曲線相関 $\left(\mathrm{R}^{2}=0.5539\right)$ が示され、マスカー 音によって音声のプライバシ一性を高めるだけでは執務者にとって 好ましい環境を実現できないことが示された。なお T/M 比が-2 $\mathrm{dB}$ の条件は、最も好ましいとされる範囲内にあることが確認された。

\section{5. マスカー音の周波数特性が執務における妨害感に及ぼす影響}

マスキングレベルの検討に加えて、マスカー音の周波数特性を考 慮することによって、作業への妨害感に及ぼす影響を低減できるか について検討した。

ここでは、実際の実験条件で被験者位置で測定した漏洩音の周波 数特性（T/M 比- $2 \mathrm{~dB}$ の条件における再生条件）をもとに、ピンク ノイズと環境音の 2 つの音源の周波数特性を漏洩音の音声の周波数 特性に合わせてオクターブバンドごとにレベル調整した加工音源を マスカー音として使用した。漏洩音の音声と同一の $\mathrm{A}$ 特性音圧レベ ルになるよう調整したマスカー音の周波数特性を、調整前の特性と 併せて図 11 に示す。なお図中の縦軸は、3つの音源の $\mathrm{A}$ 特性音圧

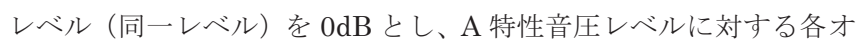
クターブバンドレベルを相対音圧レベルとして示している。この調 整後のマスカーの周波数特性をもとに、マスカー音の再生レベルを 調整して $\mathrm{T} / \mathrm{M}$ 比が $+8 \mathrm{~dB} 、+3 \mathrm{~dB} 、-2 \mathrm{~dB} 、-7 \mathrm{~dB} 、-12 \mathrm{~dB}$ の 5 条件を 設定した。

主観評価は、4 章の実験と同様に、「作業への妨害感」について 5 段階のカテゴリー評価（表 4）を行った。被験者及びスピーカの配 置は 2 章の実験条件（図 2） と同様である。実験条件は、マスカー 音としてピンクノイズと環境音の 2 種を用い、被験者に与える作業 条件は「PC 作業」と「対面会話」の 2 条件とした。背景騒音（空 調音）のレベルは $40 \mathrm{~dB}$ である。マスカー音の再生方向と再生レベ ルは 4 章の実験と同様で、マスカー種ごとに T/M 比の条件をランダ ムに提示して行うことを 1 シリーズとし、作業条件ごとに時間をあ けて実験を行い、さらにマスカーの再生方向の条件を変えて実験を 行った。被験者は 20 代学生 10 名である。

「作業への妨害感」の結果を図 12 に示す。これをみると、ピンク ノイズ、環境音ともに、調整前後で差異（有意水準 $5 \%$ 10\%）が 確認され、周波数特性を調整したことで作業への妨害感を軽減でき る傾向が示された。よって、マスカーの周波数特性をマスキーとな る音源の周波数特性に合わせることによってマスキング効率の向上 が期待できるとされていることに加えて、漏洩音による連続した侵 入音がある場合について、マスカー音の妨害感が低減できる可能性 が示唆されたと考えられる。

以上の結果から、サウンドマスキングにおいて、マスカー音の再 生レベルだけでなく、マスカー音の音質に関する考慮も必要である ことが示唆された。
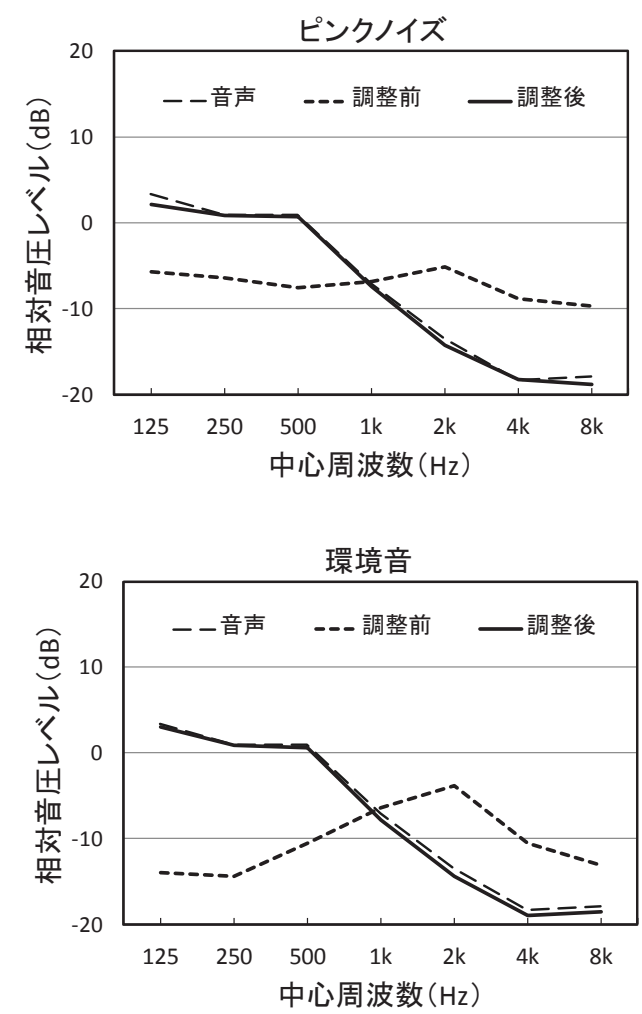

図 11 マスカー音の周波数特性
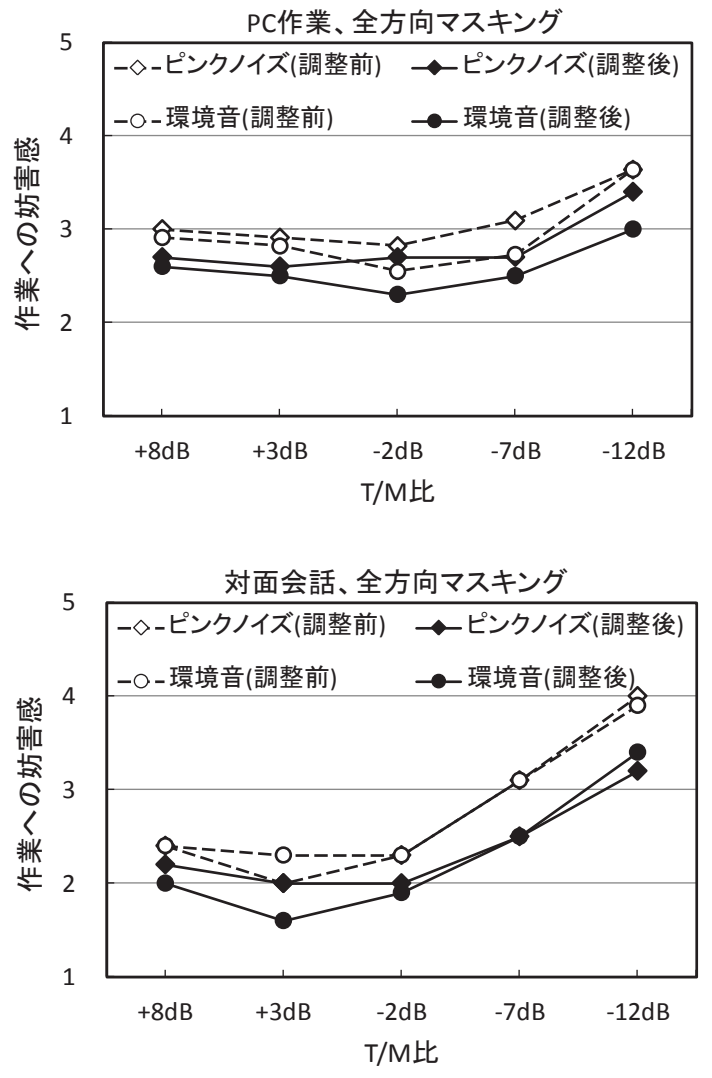

図 12 作業への妨害感の比較 


\section{6. まとめ}

執務作業時のサウンドマスキングにおける適正なマスキング条件 について、隣接空間からの漏洩音の了解性とマスカー音による執務 作業時の妨害感についての主観評価実験を行った結果、今回の実験 条件の範囲内での検討ではあるが、以下の知見が得られた。

（1）漏洩音の了解性の評価から、作業時は非作業時よりもマスカ ーレベルを「PC 作業」では約 $5 \mathrm{~dB}$ 以上、「対面会話」では約 $10 \mathrm{~dB}$ 以上低く設定できる可能性があり、作業時の必要マスキングレベル は「PC 作業」では-7dB、「対面会話」では-2dBの条件が示された。

（2）執務者に対して（水平）全方向からを再生するより、漏洩音 の到来方向と同方向からマスカー音を再生する方向性マスキング （同方向）とする方が、漏洩音の了解性を低下させることに有効であ ることが示唆された。

（3）執務作業時の妨害感の評価から、許容できると判断されたマ スキングレベルは、 $\mathrm{T} / \mathrm{M}$ 比が $-2 \mathrm{~dB} \sim+3 \mathrm{~dB}$ となる条件となり、（1） で示した漏洩音の了解性の面から必要となるマスキングレベルが $\mathrm{T} / \mathrm{M}$ 比が-7dB〜-2dB 以下となる条件であったことと併せて判断す ると、両評価の条件を共に満たす $\mathrm{T} / \mathrm{M}$ 比の範囲 $(-2 \mathrm{~dB})$ を作業時 における適正なマスキングレベルとして提案できる。

（4）マスカー音の周波数特性を考慮することによって「作業への 妨害感」を軽減できる可能性が示唆された。

今回の実験結果から上記のようなマスキング条件に関する検討を 行ったが、実際のオフィスにおいては、必ずしも執務作業環境が常 に同じ状態にあるとは限らない。よって、オフィスの場面や状況ご とに要求される環境にあわせたサウンドマスキングの運用を考える 場合には、漏洩音の了解性と執務作業時の妨害感から判断された $\mathrm{T} / \mathrm{M}$ 比の条件（-2dB）を基本設定とし、会話のプライバシー性を保 護することと作業への妨害感を低減させることの、どちらに重点を 置くかによって T/M 比（-7dB〜- $2 \mathrm{~dB} \sim+3 \mathrm{~dB})$ の範囲内でマスキン グレベルを調整することが望ましいと考える。

\section{参考文献}

1) W.J.Cavanaugh, W.R.Farrell, P.W.Hirtle, and B.G.Watters : Speech Privacy in Buildings, J. Acoust. Soc. Am.,34(4), pp.475-492, 1962

2) 羽入 敏樹他：調剂薬局におけるスピーチプライバシー保護：その 2 パ 一ティションおよびサウンドマスキングの効果, 日本建築学会大会学術講 演梗概集.D-1, pp.297-300, 2008

3）李 孝珍 他: 調剤薬局におけるサウンドマスキングシステムの効果に関す る実験室実験，日本音響学会建築音響研究会資料, AA2012-15

4) 佐藤 逸人 他：病院診察室におけるスピーチプライバシーの心理評価，日 本音響学会講演論文集, 2012 (秋季)

5）小林 秀彰 他:オフィス空間へのサウンドマスキングの適用に関する研究, 日本音響学会建築音響研究会資料, AA2011-34

6）池上 雅之 他：会議室の遮音対策におけるサウンドマスキング用 BGM $の$ 音量設定に関する検討, 日本建築学会大会学術講演梗概集.D-1, pp.345-346, 2010

7) ASTM E1130-02e1 : Standard Test Method for Objective Measurement of Speech Privacy in Open Offices Using Articulation Index, ASTM International, West Conshohocken, PA, 2002

8) ISO/DIS 3382-3 : Acoustics-Measurement of room acoustic parameters -Part3 : Open plan offices, 2012

9) A.C.C.Warnock : Acoustical privacy in the landscaped office, ASTM International, J. Acoust. Soc. Am., 53(6), 1973

10）清水 寧 他：会話音による「収束的思考の妨害感」の低減を目的としたマ スキング音の評価一衝立で囲まれた個人スペースの場合一, 日本音響学会 建築音響研究会資料, AA2012-14

11）渡會 健 他：オープンプランオフィスにおけるマスキング音の評価一作 業の妨害感と喧騒感の関係について一, 日本音響学会講演論文集, 2013 (秋 季)

12）上野 佳奈子 他：サウンドマスキングシステムを用いた音環境設計・評 価のための実験的検討, 日本建築学会大会学術講演梗概集.D-1, pp.285-288, 2008

13) J.S.Bradley et al. : Some spatial and temporal effects on the speech privacy of meeting rooms, J. Acoust. Soc. Am., 125(5), 2009

14）清水 寧 他：スピーチプライバシーと際立ちー公共スペースにおける音 再生一，振動騒音制御研究会, 2009

15）藤原 舞：マスキングの原理と応用，音響技術 No.152, Vol.39 no.4, 2010

16）茨木 大輔 他：マスキング音の再生方向が音声の聴取評価に及ぼす影響 一対面会話時におけるサウンドマスキングについての考察一（その1）,日 本音響学会講演論文集, 2013 (秋季)

17) NII 音声資源コンソーシアム, NTT・東北大親密度単語了解度試験用音源 データセット（FW03）,2006

18) V.Homgisto et al. : A model predicting the effect of speech of varying intelligibility on work performance, Indoor Air, Vol.15, Issue6, 2005

19）辻村 壮平 他：教室内音環境が学習効率に及ぼす影響, 日本建築学会環 境系論文集, No.653, pp.561-568, 2010.7 


\title{
APPLICATION OF SOUND MASKING SYSTEM AT DESK WORKING IN OPEN PLAN OFFICES BASED ON SUBJECTIVE EVALUATIONS
}

\author{
Osamu HASHIMOTO* and Daisuke IBARAKI** \\ * Assoc. Prof., Dept. of Architecture, College of Science and Technology, Nihon Univ., Dr. Eng. \\ ** East Japan Railway Company, M. Eng.
}

In open plan offices with no partitions, group workstations are often directly adjacent. Individuals can be disturbed by the intrusion of unwanted speech from nearby conversations which reduces productivity in the working environment. Furthermore, privacy is compromised with a high risk that confidential conferences may be overheard. As a practical measure, open plan offices are often equipped with sound masking systems to mask conversational distractions and unwanted noise. However, masker sound has the capacity to be a source of discomfort to workers, and has the potential to jeopardize the intended effect of sound masking systems depending on the type of working environment.

The purpose of this study was to examine appropriate masking adjustments in open plan offices installed with sound masking systems. This was done by establishing an optimum balance between preserving the privacy of conversations and reducing the task disturbance of masker sound. To perform the experiments, an open plan office was simulated by setting up a desk layout in a classroom.

We conducted two subjective experiments: The effect of the sound masking system on unwanted noise interference from nearby workstations, and the degree of noise disturbance from the sound of the masker system itself. The results of the word intelligibility test and subjective judgement tests on the degree of discomfort were as follows:

(1) The result of the unintelligibility of speech tests and word intelligibility tests indicated that the level of masker sound can be decreased to 5-10 dB when focused on desk work relative to the masking level in non-desk work. The required masking level is less than or equal to the target/masker ratio of $-7 \mathrm{~dB}$ at desks where individuals work on computers, and - $2 \mathrm{~dB}$ in face-to-face conversations.

(2) In terms of decreasing the intelligibility of overheard speech, it is more effective to produce the masker sound in the same direction as intruding unwanted conversation than to produce it omnidirectionally.

(3) The result of subjective judgement tests on the degree of discomfort indicated that the acceptable upper limit of the masking level was less than or equal to the target/masker ratio of $-2-+3 \mathrm{~dB}$.

(4) Based on the results (1), we showed that the optimum masking level is a target/masker ratio of -2 $\mathrm{dB}$, fulfilling both the requirements to preserve the privacy of conversation, and to decrease the task disturbance of masker sound to people working at desks.

Altogether, it is recommended to adjust the masking level within a target/masker ratio range of $+3 \mathrm{~dB}$ from $-7--2 \mathrm{~dB}$, thereby preserving the privacy of conversations and reducing the task disturbance in the working environment. 